\title{
Contrasting Effects of Cattle Grazing Intensity on Upland-Nesting Duck Production at Nest and Field Scales in the Aspen Parkland, Canada
}

\section{Effets contrastants du pâturage par les bestiaux sur la productivité des canards des terres émergées aux échelles du nid et du champ dans la forêt-parc de peuplier faux-tremble du Canada}

\author{
$\underline{\text { Jeffrey M. Warren }}^{1}, \underline{\text { Jay Rotella }}^{1}$, and Jonathan E. Thompson $^{2}$
}

\begin{abstract}
The Aspen Parkland of Canada is one of the most important breeding areas for temperate nesting ducks in North America. The region is dominated by agricultural land use, with approximately 9.3 million ha in pasture land for cattle grazing. However, the effects of using land for cattle grazing on upland-nesting duck production are poorly understood. The current study was undertaken during 2001 and 2002 to investigate how nest density and nesting success of upland-nesting ducks varied with respect to the intensity of cattle grazing in the Aspen Parkland. We predicted that the removal and trampling of vegetation through cattle grazing would reduce duck nest density. Both positive and negative responses of duck nesting success to grazing have been reported in previous studies, leading us to test competing hypotheses that nesting success would (1) decline linearly with grazing intensity or (2) peak at moderate levels of grazing. Nearly 3300 ha of upland cover were searched during the study. Despite extensive and severe drought, nest searches located 302 duck nests. As predicted, nest density was higher in fields with lower grazing intensity and higher pasture health scores. A lightly grazed field with a pasture score of 85 out of a possible 100 was predicted to have 16.1 nests/100 ha $(95 \% \mathrm{CI}=11.7-22.1)$, more than five times the predicted nest density of a heavily grazed field with a pasture score of $58(3.3$ nests $/ 100$ ha, $95 \% \mathrm{CI}=2.2-4.5)$. Nesting success was positively related to nest-site vegetation density across most levels of grazing intensity studied, supporting our hypothesis that reductions in vegetation caused by grazing would negatively affect nesting success. However, nesting success increased with grazing intensity at the field scale. For example, nesting success for a well-concealed nest in a lightly grazed field was $11.6 \%(95 \% \mathrm{CI}=3.6-25.0 \%)$, whereas nesting success for a nest with the same level of nest-site vegetation in a heavily grazed field was $33.9 \%(95 \% \mathrm{CI}=17.0-51.8 \%)$. Across the range of residual cover observed in this study, nests with above-average nest-site vegetation density had nesting success rates that exceeded the levels believed necessary to maintain duck populations. Our findings on complex and previously unreported relationships between grazing, nest density, and nesting success provide useful insights into the management and conservation of ground-nesting grassland birds.
\end{abstract}

RÉSUMÉ. La forêt-parc de peuplier faux-tremble du Canada est l'une des plus importantes régions Nord-Américaines pour la reproduction des canards de la zone tempérée. La région est dominée par l'agriculture, avec environ 9,3 millions d'ha de pâturages réservés aux bestiaux. Toutefois, les effets de l'utilisation des terres pour le pâturage par les bestiaux sur la productivité des canards nichant dans les terres émergées sont peu connus. Cette étude a été entreprise en 2001 et 2002 afin de déterminer de quelle façon la densité et le succès de reproduction variaient en fonction de l'intensité du pâturage par les bestiaux dans la forêt-parc de peuplier faux-tremble. Nos prédictions étaient que le broutage et le piétinement de la végétation par les bestiaux réduiraient la densité de nids de canards. Des études précédentes ont rapporté des réponses positives ou négatives du succès de reproduction des canards à l'intensité du broutage, ce qui nous a amenés à tester les hypothèses compétitrices suivantes: le succès de reproduction (1) diminuera linéairement en fonction de l'intensité du broutage ou (2) atteindra un sommet à des niveaux intermédiaires de broutage. Près de 3300 ha de couvert végétal ont été inspectés dans le cadre de l'étude. En dépit d'une sécheresse intense, nos recherches ont permis de localiser 302 nids de canards. Tel que prédit, la densité était plus élevée dans les champs où l'intensité de broutage était plus faible et la qualité des pâturages était plus élevée.

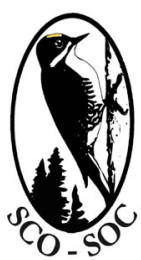

Sponsored by the Society of Canadian Ornithologists and Bird Studies Canada

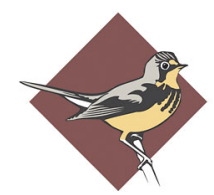

BIRD STUDIES CANADA 
Notre modèle prédit qu'un champ faiblement brouté ayant un indice de qualité de pâturage de 85 sur une échelle de 100 aurait une densité de 16,1 nids/100 ha (I.C. $95 \%=11.7-22.1$ ), soit plus de 5 fois la densité de nids prédite pour un champ brouté intensivement ayant un indice de qualité de pâturage de $58(3,3$ nids/100 ha, I.C. 95\% $=2.2-4.5)$. Le succès de reproduction était relié positivement à la densité de la végétation au site de nidification, pour la plupart des niveaux d'intensité de broutage étudiés, conformément à notre hypothèse selon laquelle la réduction du couvert végétal associée au broutage affecterait négativement le succès de reproduction. Toutefois, pour un nid bien camouflé, le succès de reproduction dans un pâturage peu intensif était de 11,6\% (I.C. 95\% = 3.6-25.0\%), alors que pour un nid aussi bien camouflé dans un pâturage intensif, il était de 33,9\%. Selon le gradient de couvert résiduel observé dans cette étude, les nids plus camouflés que la moyenne avaient un succès de reproduction supérieur au taux jugé nécessaire pour maintenir les populations de canards. Nos résultats sur les relations complexes et inconnues auparavant entre le broutage, la densité de nids et le succès de reproduction fournissent un éclairage nouveau sur la conservation et l'aménagement des populations d'oiseaux nichant au sol dans les prairies.

Key Words: Aspen Parkland; duck production; grazing; nest density; nesting success; waterfowl

\section{INTRODUCTION}

The Prairie Pothole Region (PPR) supports the highest densities of breeding waterfowl in North America. Although this region covers only $10 \%$ of the available breeding habitat for waterfowl, it can account for greater than $50 \%$ of annual continental duck production (Smith et al. 1964). The PPR is divided into two major zones, the larger being the grasslands, which cover the southern portion of the Prairie Provinces. The northern one-third (22 million ha) of the PPR, the Aspen Parkland, supported nearly half of the waterfowl that bred in the Canadian PPR during the last decade (U.S. Fish and Wildlife Service 2007).

Duck recruitment in the PPR can be limited by predation of nesting females, eggs, and ducklings (Sargeant and Raveling 1992). Predation is the dominant cause of nest loss for ducks and is therefore the primary determinant of nesting success in the PPR (Klett et al. 1988, Greenwood et al. 1995). Studies have indicated that population growth rates $(\lambda)$ for upland-nesting duck species in the PPR are highly sensitive to variation in nesting success (Johnson et al. 1992, Hoekman et al. 2002). Moreover, there is evidence that nesting success in the Canadian PPR has declined over the past 70 years (Beauchamp et al. 1996, Drever et al. 2007).

Reduced nesting success is likely related to declines in the quantity and quality of nesting habitat and changes in the abundance and distribution of predator communities, all of which are related to the intensification of agricultural land use. Most of the PPR is dominated by agricultural land use, which has led to the loss and degradation of wetland and upland habitats throughout the region. At least $80 \%$ of the Aspen Parkland has been converted to agricultural land use (Rowe 1987), and 40-63\% of wetland basins have been drained or removed since settlement (Turner et al. 1987). Currently, the dominant agricultural land use in the Aspen Parkland is the production of annual crops. Cattle grazing is the second most common land use in the Aspen Parkland, and approximately 9.3 million ha of pasture land were present in a 2001 agricultural survey (Statistics Canada 2003).

Consumption and trampling of vegetation in pastures can negatively affect the attractiveness and quality of nesting habitat for ducks (Kirsch et al. 1978). Gilbert et al. (1996) found that, during the first nesting season following moderate grazing, nest densities and nesting success were 58 and $85 \%$, respectively, of those for ungrazed areas in the Monte Vista National Wildlife Refuge, Colorado. These results support the hypothesis that increasing vegetation height and density increases nesting success, possibly by impeding predator movements and their ability to detect nests (Duebbert 1969, but see Clark and Nudds 1991). However, several studies have reported greater nesting success in pastures than in other habitats in the PPR (Barker et al. 1990, Greenwood et al. 1995), and no information is available regarding how duck production, the product of nest density and nesting success, changes across the range of grazing intensity in the Aspen Parkland. This lack of information precludes the effective management of upland habitats for nesting waterfowl with cattle grazing. Therefore, we undertook this study to evaluate relationships between intensity of cattle grazing and field-specific measures of nest density and nesting success. 


\section{Hypotheses and predictions}

Reductions in vegetation density and structural heterogeneity caused by cattle were hypothesized to: (1) reduce the number of available nest sites and thereby reduce nest density within a field (Kirsch et al. 1978, Klett et al. 1988) and (2) increase the probability that a nest would be depredated (Duebbert 1969, Sedivec 1989). We alternatively hypothesized that the relationship between grazing and nesting success would not be linear, but instead would peak at moderate levels of grazing. High levels of grazing can leave very little residual cover for nest concealment, which is particularly important in an area like the Aspen Parkland that has a diverse and abundant community of predators who prey on avian nests. Therefore, we predicted a negative linear relationship between the amount of residual cover in a field and both duck nest density and nesting success. However, Barker et al. (1990) found higher nesting success in grazed relative to ungrazed areas in the PPR. Grazed areas may attract fewer predators because of low densities of some types of prey, e.g., small mammals (Grant et al. 1982, Runge 2005), less cover for concealment, or both. We predicted that this would result in a negative quadratic relationship between field residual cover and duck nesting success such that nesting success peaked at moderate levels of residual cover.

\section{METHODS}

\section{Study area}

This study was conducted on private pasturelands, provincial grazing reserves, and Ducks Unlimited Canada properties in the western Aspen Parkland of Alberta (Fig. 1). The region is dominated by agricultural land use with cereal grains, oil seeds, and cattle as the major products. Season-long grazing is typical, with cattle pastured May through October. The topography is undulating to hilly, with black chernozemic soils as the dominant soil type. Mid-continent weather extremes characterize the Parkland, with average temperatures of $-13.4^{\circ} \mathrm{C}$ for January and $16.5^{\circ} \mathrm{C}$ for July (Environment Canada 2006). Average annual precipitation is approximately $48 \mathrm{~cm}, 50 \%$ of which falls during the summer months of June to August (Environment Canada 2006). However, wetlands in the Aspen Parkland are largely dependent upon spring runoff for annual recharge.

\section{Field methods}

We selected eight clusters of fields each year. Each of the six treatments described below was represented in each cluster by at least one field. Fields ranged in size from 32 to 130 ha and were selected so that proximity to other fields was $\geq 1.6$ $\mathrm{km}$, whereas each cluster's radius was minimized $(\leq 17.2 \mathrm{~km})$ to help ensure that within-cluster fields experienced a similar suite of ecological regimes, e.g., predator communities, precipitation. New clusters and fields were selected each year.

Fields were selected based on two classes of grass type and three classes of grazing intensity. Grass types were (1) tame and (2) native/naturalized. Grazing intensity was categorized based on ocular estimation of percent utilization of vegetation by cattle during the previous year and was characterized as either heavy ( $>65 \%$ utilization), moderate (33-65\% utilization), or low/idle $(<33 \%$ utilization). Categorization was approximate and done prior to data collection to select potential sites before access was obtained. To quantify withinfield residual cover, we averaged Robel pole (Robel et al. 1970) visual obstruction measurements taken at 30 randomly selected points during the first nest search (see nest monitoring methods below). These measurements were repeated during the third nest search to quantify the field trend in vegetation density over the breeding season, i.e., the firstsearch measurements subtracted from the thirdsearch measurements for each field. Within each field, we measured range/pasture health on 10 plots using a standard assessment method (Adams et al. 2000). The assessment determines the ability of rangeland to sustain functions such as net primary production, soil stability, nutrient cycling, and plant species functional diversity on a scale from 0 to 100 (Adams et al. 2000). Pastures scoring 75-100 are considered "healthy"; 50-74, "healthy with problems"; and < 50 "unhealthy." Plot scores were averaged for each field for an overall score that was used in analysis.

The area of woodland and wetland habitats in each field was digitized using aerial photographs at 1:30,000 scale. The proportion of woodland and wetland habitats within each field was then calculated. Each field was also categorized based on the percent of searched area containing shrub cover (class $0, \leq 5 \%$ of the searched area contained shrubs; class I, 6-20\%; class II, 21-50\%; class III, > $50 \%$ ). Field wetland basins were visited in July to 
Fig. 1. Location of study sites in the western Aspen Parkland of Alberta, Canada, 2001-2002. A cluster consisted of a grouping of each of the six treatment types based on grazing intensity (heavy, moderate, and low/idle) and grass type (native/naturalized and tame).

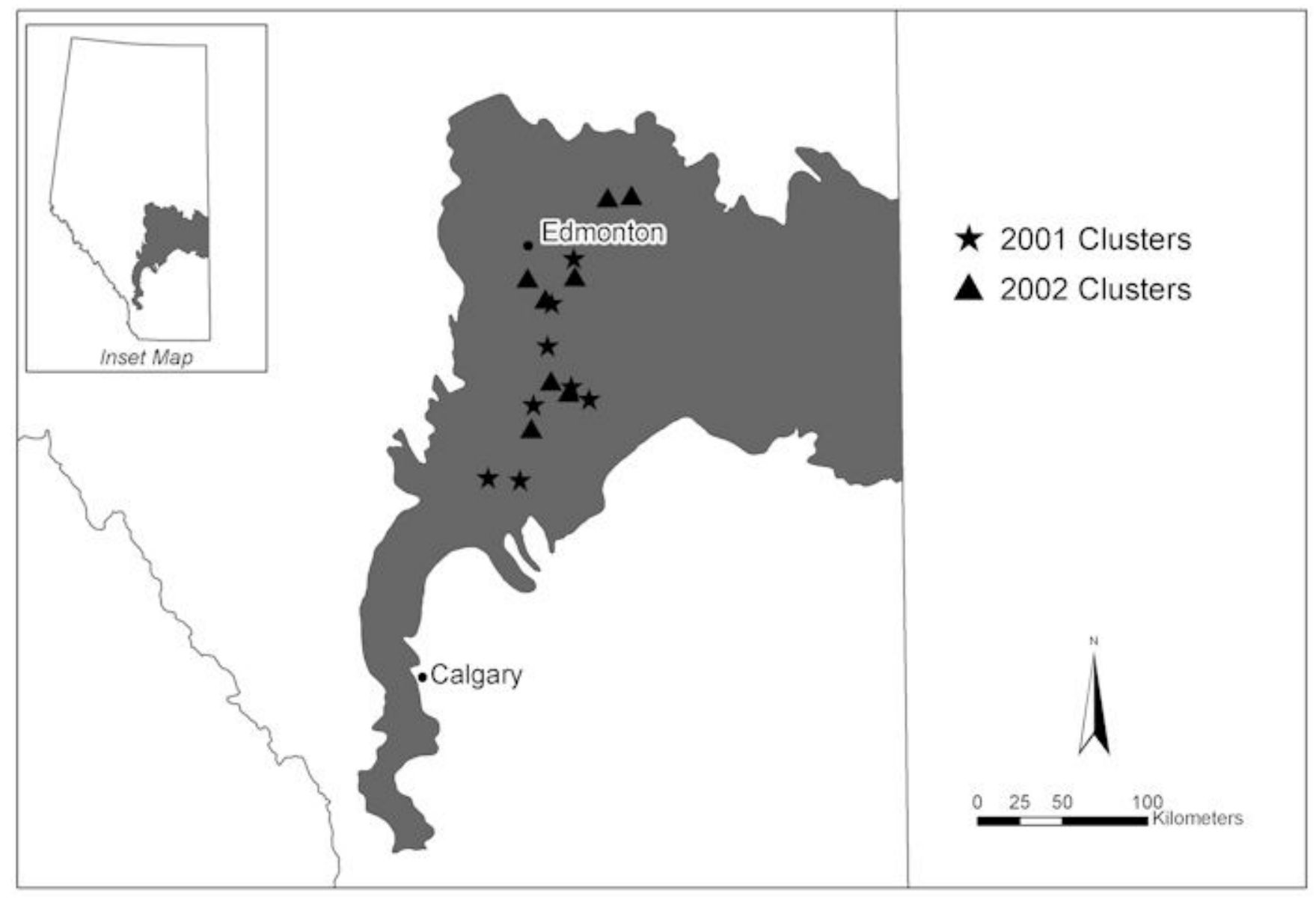

classify water permanency based on vegetation communities (Stewart and Kantrud 1971). The proportion of flooded class III-V wetland basins (Stewart and Kantrud 1971) was estimated for each field as an index of wetland conditions.

Grassland, shrubland, and dry wetland areas were systematically searched for duck nests by twoperson crews using cable-chain drags towed by allterrain vehicles (Klett et al. 1986). Each field was searched three times per summer, with approximately three weeks separating each search. Upland area searched for each field was calculated by digitizing the total area searched and subtracting flooded wetland area (see above).
For each nest, the Universal Transverse Mercator position, habitat type (grassland, shrubland, wetland), and nest initiation date as estimated by field-candling eggs (Weller 1956) were recorded. Nests were revisited every 6-10 d until fate was determined, i.e., at least one egg hatched or the nest was destroyed or abandoned. The vegetation physiognomy of each nest was quantified using a Robel pole and by recording nest-site vegetation height to the nearest $5 \mathrm{~cm}$, up to a maximum of 1.5 $\mathrm{m}$. These measurements were taken when nests were found during the first field season and at each subsequent visit to a nest during the second season. Robel visual obstruction measurements were taken at each of the four cardinal directions with the pole 
immediately north of the nest, and the measurements were averaged for an estimate of nest-site vegetation density.

\section{Data analysis}

To determine the amount of support for each of our predictions and hypotheses of interest for each of the two components of duck production studied, we assessed suites of a priori models that expressed competing ideas regarding patterns of variation in each response variable (Burnham and Anderson 1998). We evaluated the strength of support for each model by ranking models with Akaike's Information Criterion corrected for small sample sizes $\left(\mathrm{AIC}_{\mathrm{c}}\right)$ and by calculating the normalized relative model likelihoods $\left(\omega_{\mathrm{i}}\right)$ for each model (Burnham and Anderson 1998).

\section{Nest density}

The total number of duck nests found in upland grassland and shrubland habitats within a field was modeled using various combinations of habitat covariates measured at the nest site or study site. Models were evaluated in Proc GENMOD of SAS (SAS Institute 2001) using a negative binomial distribution of errors that is useful for clumped data, as might be expected for counts of nests (White and Bennetts 1996), and a log-link function. Model goodness-of-fit was tested with the estimated deviance assuming a $\chi^{2}$ distribution with $n-k$ degrees of freedom, where $n$ is the sample size and $k$ is the number of estimated parameters (Neter et al. 1996). To control for differences in wetland conditions among fields that may have affected settling patterns of breeding ducks, and therefore nest density (Johnson and Grier 1988), the proportion of flooded basins was also included in each model.

\section{Nesting success}

We evaluated competing models of daily survival rates (DSR) for nests using Proc NLMIXED (SAS Institute 2001), a binomial error distribution, a logit link, and methods specific to nest survival data that allow greater flexibility in modeling potential covariate effects (Rotella et al. 2004, 2007). Goodness-of-fit was evaluated for both the most parameterized model and the best supported model in our model set (Sturdivant et al. 2007).
Nests abandoned, damaged, or destroyed because of investigator activity were not included in the analysis. During 2001, nest vegetation measurements were taken only when a nest was found (see Methods above). Therefore, the initial nest vegetation measurement was used as a constant co-variate for each nest found during 2001, whereas intervalspecific nest vegetation data were used for nests found in 2002. Once estimates for DSR were obtained, nesting success was calculated as $(D S R)^{\mathrm{t}}$, where $t$ is the average number of days from initiation to hatch for upland-nesting ducks $(t=35$ for the species used in this analysis).

Univariate models of nest survival containing nest age or Julian date were analyzed to look for evidence that would warrant the inclusion of one or both of these co-variates in nesting success models. If $95 \%$ confidence intervals for the coefficient in question did not include 0 , then the variable was considered in all subsequent models. Additionally, to evaluate possible heterogeneity in DSR that went unexplained by the co-variates measured during the study, we considered site and cluster as potential random effects. By comparing $\mathrm{AIC}_{\mathrm{c}}$ values for models without a random effect vs. those with either site or cluster as a random effect, we were able to assess the importance of these factors in explaining heterogeneity in DSR.

We calculated duck production as the product of nest density and nesting success using the most parsimonious model from each component. Duck production as used here is, therefore, a prediction of the number of hatched nests on a site.

\section{RESULTS}

A total of 3290 ha of upland habitat was searched across 97 different fields. Four fields were used in both years because of difficulties in obtaining suitable replacements. Nest searches located a total of 302 duck nests spread among 62 fields; 35 fields contained no nests. We found 234 nests in upland habitats and 68 in wetland habitats. Blue-winged Teal (Anas discors) nests accounted for $49 \%$ of the sample; Gadwall (A. strepera), 16\%; Northern Shoveler (A. clypeata), 15\%; Mallard (A. platyrhynchos), $11 \%$; Lesser Scaup (Aythya affinis), 5\%; Green-winged Teal (Anas crecca), 3\%; Cinnamon Teal (A. cyanoptera),$<1 \%$; and Redhead (Aythya americana), $<1 \%$. 


\section{Vegetation and habitat conditions of fields}

Data were collected across a broad gradient of grazing intensity and habitat conditions found in the Aspen Parkland. Field-specific residual cover (RC) ranged from $<0.01$ to $1.55 \mathrm{dm}$ in 2001 and from 0 to $0.75 \mathrm{dm}$ in 2002 . Mean RC for native fields was $0.37 \mathrm{dm}$ in $2001(95 \% \mathrm{CI}=0.21-0.52)$ and $0.16 \mathrm{dm}$ in $2002(95 \% \mathrm{CI}=0.09-0.23)$. Tame field mean $\mathrm{RC}$ was $0.39 \mathrm{dm}$ in $2001(95 \% \mathrm{CI}=0.24-0.55)$ and 0.29 $\mathrm{dm}$ in $2002(95 \% \mathrm{CI}=0.18-0.40)$. The mean proportion of wetland area by field was $21.3 \%(95 \%$ $\mathrm{CI}=18.8-23.7 \%)$ in 2001 and $22.5 \%(95 \% \mathrm{CI}=$ $19.2-25.8 \%$ ) in 2002 and did not differ among grazing intensity categories $\left(F_{2,94}=1.23, P=\right.$ 0.298). The drought conditions experienced during the study were evident in the proportion of wetland basins containing water during July. During 2001, 561 of $2271(24.7 \%)$ wetlands contained water, whereas only 155 of $1665(9.3 \%)$ wetlands contained water in 2002. Of these basins, $4.8 \%$ and $<1 \%$ contained flooded emergent vegetation in 2001 and 2002, respectively.

\section{Nest density}

When data from nests in upland habitats were analyzed, the most general nest density model provided a suitable fit to the data $\left(\chi^{2}=105.20, \mathrm{df}=\right.$ $92, P=0.16)$. In keeping with our prediction that the number of available nest sites for upland-nesting ducks is reduced by cattle grazing, we found that nest density was higher in pastures with more residual cover and higher scores for pasture health (Fig. 2). The two most parsimonious models, DEN (proportion of flooded basins + residual cover + pasture score + year) and DEN(proportion of flooded basins + residual cover + pasture score), received the majority of support $\left(\sum \mathrm{w}_{\mathrm{i}}=0.778\right)$ and had $\mathrm{AIC}_{\mathrm{c}}$ values that were within 0.78 units of each other (Table 1). Each model suggested that duck nest density was positively affected by the proportion of flooded wetland basins, residual cover, and pasture score. The best model also indicated a weak relationship between duck nest density and year. Coefficient estimates for RC and PS were positive in both models [DEN(proportion of flooded basins + residual cover + pasture score + year): $\beta_{\mathrm{RC}}=1.723,95 \% \mathrm{CI}=0.967-2.479, \beta_{\mathrm{PS}}=$ $0.020,95 \% \mathrm{CI}=0.006-0.035$; DEN(proportion of flooded basins + residual cover + pasture score): $\beta_{\mathrm{RC}}=1.514,95 \% \mathrm{CI}=0.842-2.186, \beta_{\mathrm{PS}}=0.023$, $95 \% \mathrm{CI}=0.010-0.037]$. These two co-variates were also correlated (Pearson's product-moment correlation, $r=0.46, P<0.01$ ), such that fields with more residual cover had higher pasture health scores. However, the correlation was not significant at PS values $>57(r=0.19, P=0.191)$. The estimated coefficient for year in the most parsimonious model, DEN(proportion of flooded basins + residual cover + pasture score + year), provided weak support for higher nest densities during the second field season $(0.430,95 \% \mathrm{CI}=-0.137$ to 0.996$)$. Our results indicated that nest densities were much higher in healthy pastures with high levels of residual cover than they were in poorly managed, overgrazed pastures. For example, a lightly grazed (90\% quantile residual cover) 100-ha field with a pasture score of 85 (90\% quantile) was predicted to have 16.1 nests $(95 \% \mathrm{CI}=11.7-22.1)$ during the study, whereas a heavily grazed $(10 \%$ quantile residual cover) 100-ha field with a pasture score of 58 was predicted to have 3.3 nests (2.2-4.5). Because data were limited for fields with high levels of cover, further data would be needed to explore possible nonlinear effects between residual cover and nest density.

\section{Nesting success}

Of the 302 nests found, 32 were abandoned, damaged, or destroyed because of research activities. The remaining 270 were suitable for analysis and yielded data for 633 nest revisit intervals that were used for modeling DSR. Goodness-of-fit statistics indicated that our most complex model $(P=0.16)$ and our best-supported model $(P=0.62)$ both fit the data. Evidence for a relationship between DSR and either nest age or Julian date was weak $(0.001,95 \% \mathrm{CI}=-0.015$ to $0.018 ; 0.005,95 \%$ CI $=-0.004$ to 0.014 , respectively), and these co-variates were not included in well-supported models. Similarly, including random site or cluster effects in models did not improve DSR model rankings.

We found strong evidence that nesting success was affected by vegetation characteristics influenced by cattle grazing. Our prediction of a positive linear relationship between nesting success and vegetation density was supported at the nest-site scale. However, at the field scale, nesting success tended to increase with decreasing vegetation density. The most parsimonious model contained nest-site vegetation density $(0.322,95 \% \mathrm{CI}=0.107-0.537)$ 
Fig. 2. Predicted nest density and 95\% CIs (dotted lines) in the Aspen Parkland of Alberta, Canada, in relation to field residual cover (RC) and pasture health score, averaged over both study years and based on the nest density model DEN (proportion of flooded basins + residual cover + pasture score; $n=100$ fields). Mean proportion of flooded wetland basins within a study site (PBASIN $=0.2547$ ) was used in the model. The co-variates RC and pasture health score are correlated across all values (Pearson's product-moment correlation, $r=0.459, P<0.01)$, but the correlation is nonsignificant at pasture health score values $>57(r=0.190, P=0.191)$.
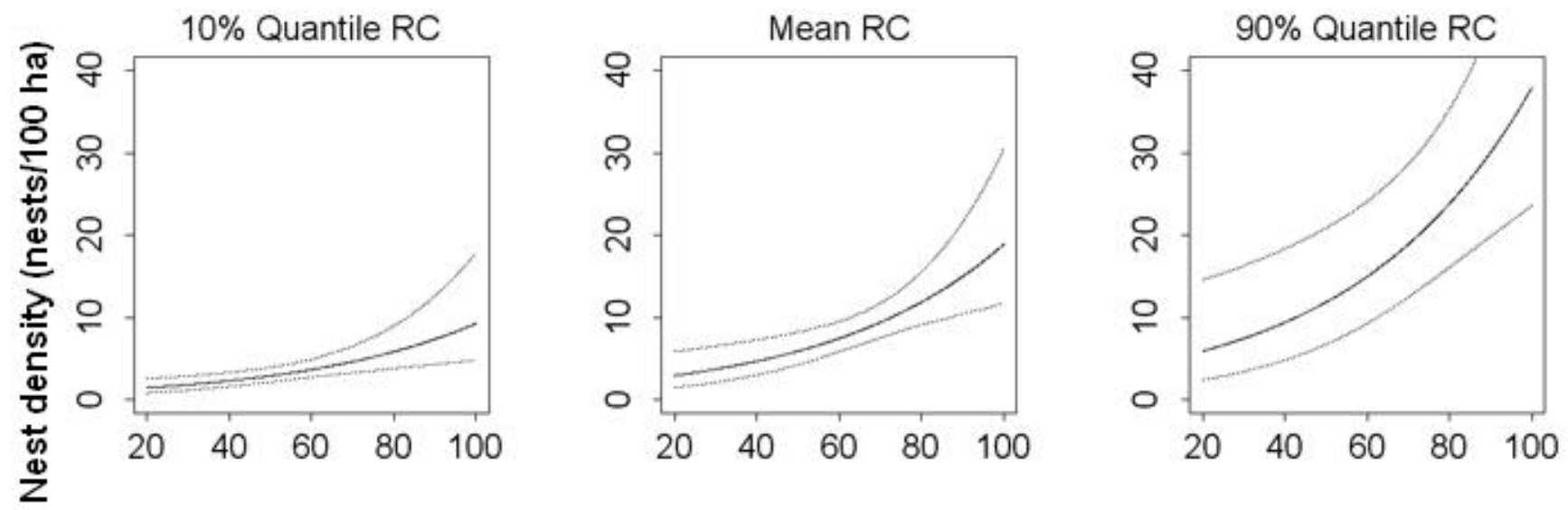

Pasture health score

and field residual cover $(0.766,95 \% \mathrm{CI}=-0.085$ to 1.616), and an interaction between these two covariates $(-0.373,95 \% \mathrm{CI}=-0.732$ to -0.014 ; Table 2 ). Because of this interaction, the positive relationship between nesting success and nest-site vegetation density was dependent upon the level of residual cover in the surrounding field (Fig. 3). For example, increasing nest-site vegetation density from the $10 \%(1.0 \mathrm{dm})$ to $90 \%(4.0 \mathrm{dm})$ quantile in a field with high levels of residual cover $(0.99 \mathrm{dm}$; $90 \%$ quantile) resulted in a slight decline in nesting success: from $15.3 \%(95 \% \mathrm{CI}=7.1-26.5 \%)$ to $11.6 \%(95 \% \mathrm{CI}=3.6-25.0 \%)$. In contrast, the same increase in nest-site vegetation density in a field with low levels of residual cover $(0.02 \mathrm{dm} ; 10 \%$ quantile) would result in nesting success increasing greatly: from $6.6 \%(95 \% \mathrm{CI}=2.6-13.4 \%)$ to $33.9 \%$ $(95 \% \mathrm{CI}=17.0-51.8 \%)$. Our results indicated that (1) females who selected densely vegetated nest sites within heavily grazed fields tended to have the highest nesting success and (2) nest-site vegetation density became increasingly important to nesting success as grazing reduced the amount of residual cover in a field. Because blue-winged teal accounted for nearly half of the nests found, we conducted all nesting success analyses separately for blue-winged teal nests. Results from these analyses were similar to those from analyses conducted using the full data set.

Our prediction that DSR would be highest at moderate levels of grazing, i.e., a negative quadratic relationship, was not supported. Two models that included $\mathrm{RC}^{2}$ were within $0.5 \mathrm{AIC}_{\mathrm{c}}$ units of the most parsimonious model (Table 2). In each of these models, the estimated coefficients relating $\mathrm{RC}^{2}$ to nest survival were positive, but imprecise [DSR (nest-site vegetation*residual cover + residual cover $^{2}+$ woodland area + wetland area): $\beta_{\mathrm{RC}}{ }^{2}=$ $0.788,95 \% \mathrm{CI}=-0.297$ to 1.872 ; DSR(nest-site vegetation*residual cover + residual $\left.\operatorname{cover}^{2}\right): \beta_{\mathrm{RC}}{ }^{2}$ $=0.652,95 \% \mathrm{CI}=-0.403$ to 1.707$]$. 
Table 1. Rankings of duck nest density (DEN) models investigating effects of grass type (GT) and grazing co-variates, and year (YEAR). Grazing co-variates include residual cover (RC), residual cover field trend (FTREND), and pasture score (PS). All models contain a co-variate to control for field-specific water conditions (proportion of flooded basins or PBASIN). Models are generalized linear models with a negative binomial error distribution ( $n=100$ fields). Only models within the $95 \%$ confidence interval group of models, i.e., $\Sigma \mathrm{w}_{\mathrm{i}}=0.95$, are presented (Burnham and Anderson 1998).

\begin{tabular}{lccc}
\hline \hline Model $^{\dagger}$ & $k^{\ddagger}$ & $\Delta$ AIC $_{\mathrm{c}}^{\S}$ & $w_{\mathrm{i}}^{{ }^{\prime}}$ \\
\hline DEN(PBASIN+RC+PS+YR) & 5 & 0.00 & 0.465 \\
DEN(PBASIN+RC+PS) & 4 & 0.78 & 0.315 \\
DEN(PBASIN+RC*FTREND) & 5 & 3.77 & 0.071 \\
DEN(PBASIN+RC+YR) & 4 & 4.00 & 0.063 \\
DEN(PBASIN+RC+FTREND+GT+YR) & 6 & 4.63 & 0.046 \\
\hline
\end{tabular}

${ }^{\dagger}$ Models including interaction terms include all main effects.

${ }^{\ddagger}$ Number of estimated parameters.

$\S$ The difference in $\mathrm{AIC}_{\mathrm{c}}$ scores between the present model and the best model $\left(\mathrm{AIC}_{\mathrm{c}}=107.10\right)$.

INormalized relative model likelihoods.

Based on our combined results for nest density and nesting success, upland nesting duck production is predicted to be greatest in lightly grazed or idled fields (Fig. 4). Females showed strong selection for nesting in these fields, but females selecting nest sites with above average nest-site vegetation density in fields with low levels of residual cover had higher nesting success. Higher production in lightly grazed or idled fields was largely driven by the strong response of nest density to residual cover, overwhelming the observed increase in nesting success for females selecting atypical nest sites. Additionally, females nesting at sites with aboveaverage nest-site vegetation density tended to exceed the level of nesting success believed necessary to sustain a mallard population (Cowardin et al. 1985, Klett et al. 1988). The only exception was in fields with high levels of residual cover (> 90\% quantile; $0.99 \mathrm{dm}$ ), in which nesting success was $<15 \%$ for females selecting densely vegetated nest sites.

\section{DISCUSSION}

Our results revealed complex relationships between cattle grazing in the Aspen Parkland and duck nest density and nesting success. Our hypothesis regarding the effect of cattle grazing on duck nest density was supported by the strong positive relationship between duck nest density and fieldscale residual cover. These results are consistent with earlier work in the grasslands of the PPR that suggested a positive response of duck nest density to vegetation density (Kirsch et al. 1978, Klett et al. 1988). Our results indicated a more complex relationship among nesting success, grazing intensity, and nest-site vegetation. Nest-site vegetation positively influenced nest survival across most levels of field residual cover studied. However, the slope of this relationship depended on the amount of vegetation in the surrounding field, with the strongest relationship, i.e., steepest slope, occurring in fields with low levels of residual cover because of grazing. Additionally, nesting success was highest at nest sites with high nest-site vegetation densities and low levels of residual cover in the surrounding field. 
Table 2. Rankings of duck nest daily survival rate (DSR) models investigating effects of habitat and grazing co-variates. Habitat co-variates include grass type (GT), nest habitat (NHAB), woodland area (WOA), and wetland area (WEA); grazing co-variates are nest-site vegetation density (NVEG), nest-site vegetation height $(\mathrm{NVH})$, and residual cover $(\mathrm{RC})$ co-variates. Models are nonlinear mixed effects models with a binomial error distribution ( $n=633$ nest-fate intervals). Only models within the $95 \%$ confidence interval group of models, i.e., $\Sigma \mathrm{w}_{\mathrm{i}}=0.95$, are presented (Burnham and Anderson 1998).

\begin{tabular}{|c|c|c|c|}
\hline Model $^{\dagger}$ & $k^{\dot{\xi}}$ & $\Delta \mathrm{AIC}_{\mathrm{c}}^{\S}$ & $w_{\mathrm{i}}^{l}$ \\
\hline DSR(NVEG*RC) & 4 & 0.00 & 0.143 \\
\hline DSR(NVEG) & 2 & 0.24 & 0.126 \\
\hline $\mathrm{DSR}\left(\mathrm{NVEG} * \mathrm{RC}+\mathrm{RC}^{2}+\mathrm{WOA}+\mathrm{WEA}\right)$ & 7 & 0.32 & 0.122 \\
\hline $\mathrm{DSR}\left(\mathrm{NVEG} * \mathrm{RC}+\mathrm{RC}^{2}\right)$ & 5 & 0.45 & 0.114 \\
\hline DSR(NVEG*RC+WOA+WEA) & 6 & 0.47 & 0.113 \\
\hline DSR(NVEG+GT) & 3 & 1.05 & 0.084 \\
\hline DSR(NVEG*RC+GT) & 5 & 1.25 & 0.077 \\
\hline $\mathrm{DSR}\left(\mathrm{NVEG} * \mathrm{RC}+\mathrm{RC}^{2}+\mathrm{GT}\right)$ & 6 & 2.03 & 0.052 \\
\hline DSR(NVEG+NVH) & 3 & 2.24 & 0.047 \\
\hline DSR(NVEG+NHAB) & 4 & 3.26 & 0.028 \\
\hline DSR(NHAB) & 3 & 4.72 & 0.013 \\
\hline DSR(WOA) & 2 & 4.84 & 0.013 \\
\hline DSR(Null) $)^{\mathbb{I}}$ & 1 & 5.26 & 0.010 \\
\hline DSR(WEA) & 2 & 5.34 & 0.010 \\
\hline
\end{tabular}

${ }^{\dagger}$ Models including interaction and/or quadratic terms include all main effects.

Number of estimated parameters.

§The difference in $\mathrm{AIC}_{\mathrm{c}}$ scores between the present model and the best model $\left(\mathrm{AIC}_{\mathrm{c}}=765.37\right)$.

INormalized relative model likelihoods.

IIntercept-only model.

Grazing had both immediate and longer-term effects on duck nest densities. The immediate effect was evident in the positive relationship we found between nest density and field-scale residual cover. Although the effect of drought was evident in the overall low nest densities during the study, we found significantly lower nest densities in fields with low levels of residual cover than in densely vegetated fields. Kruse and Bowen (1996) indicated that upland-nesting ducks preferred nest sites with vegetation visual obstruction measurements $\geq 0.5$ $\mathrm{dm}$. During this study, only 25 of the 97 fields had mean residual cover estimates that exceeded this value, but those 25 fields accounted for $\sim 50 \%$ of the nests found.

We also found that pasture health, which relates historical grazing management and ecological 
Fig. 3. Predicted duck nesting success and 95\% CIs (dotted lines) in the Aspen Parkland of Alberta, Canada, in relation to nest-site vegetation density and field residual cover (RC), based on the most parsimonious nesting success model DSR (nest-site vegetation density*residual cover; $n=633$ nest-fate intervals). Nest-site vegetation density was quantified as the mean of four visual obstruction measurements taken at each nest in each of the cardinal directions. Nest-site vegetation density and RC were not correlated (Pearson's product-moment correlation, $r<0.01, \mathrm{P}=0.83$ ). The horizontal dashed line represents the hypothesized threshold level of nesting success $(0.15)$ believed necessary to maintain a mallard population (Cowardin et al. 1985, Klett et al. 1988). The vertical line represents the average nest-site vegetation density $(2.2 \mathrm{dm})$ during the study.
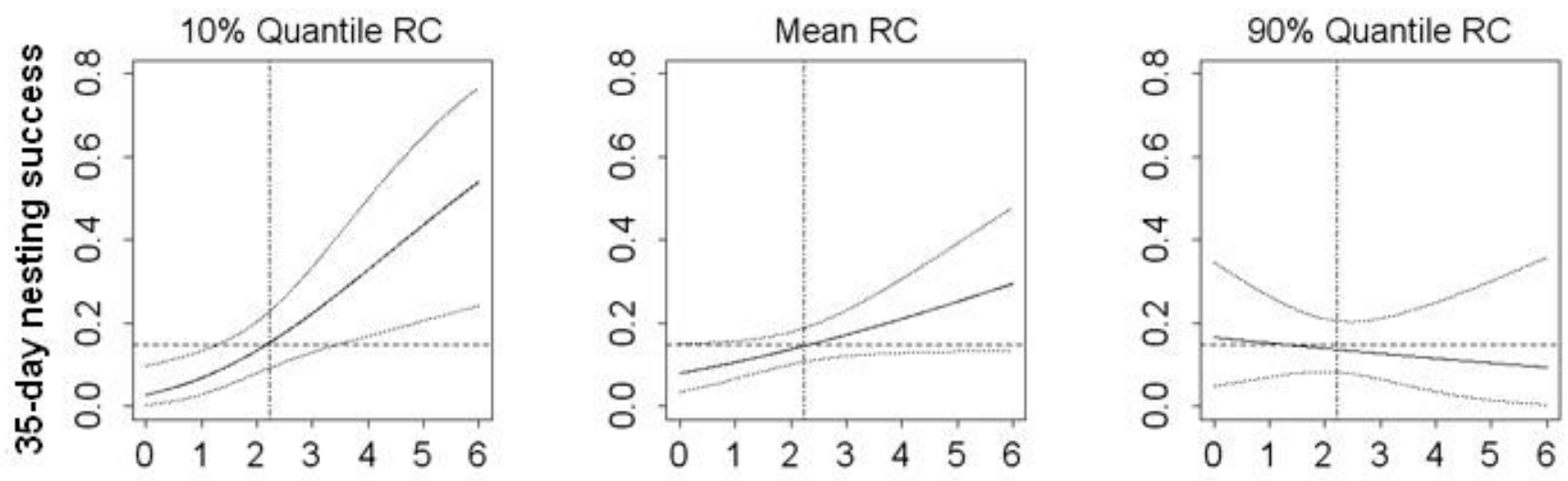

Nest-site vegetation density

function, positively influenced nest density, suggesting that grazing management can have longterm consequences for duck nest density. Fields that scored high for pasture health generally had more duck nests than lower-scoring fields. The negative effects of long-term overgrazing are many (Holechek et al. 1999) and frequently lead to conditions that result in reduced pasture health. Although long-term overgrazing commonly leads to increased shrub cover (Holechek et al. 2004), which could benefit some upland nesting waterfowl (Duebbert et al. 1986), mechanical and chemical treatment of shrubs and forbs in heavily grazed pastures is common (e.g., Bowes and Spurr 1996), and thus possible benefits typically go unrealized.

The nesting success of upland-nesting ducks in the PPR is generally believed to be positively related to nest-site vegetation density (Duebbert 1969,
Sedivec 1989). However, higher nesting success in pasturelands than in other habitats in the PPR has also been suggested (Barker et al. 1990, Greenwood et al. 1995). Our results may help explain this seeming contradiction among the results of earlier studies; we found evidence for both the importance of nest-site vegetation to nesting success and increased success of females nesting in grazed areas. Across most levels of residual cover, nesting success improved as nest-site vegetation density increased, supporting our hypothesis of a positive relationship between nesting success and vegetation density. Increasing vegetation density at the nest site would provide duck nests greater concealment from predators (e.g., Sugden and Beyersbergen 1987), the primary cause of nest failures in the PPR (Klett et al. 1988, Greenwood et al. 1995). At the larger field scale, however, we found that nesting success generally increased with grazing intensity, i.e., 
Fig. 4. Predicted duck production (successful nests/100 ha) in the Aspen Parkland of Alberta, Canada, in relation to nest-site vegetation density (NVEG), field residual cover, and pasture health score (PS), based on the product of the most parsimonious nest density and nesting success models $(n=100$ fields and 633 nest-fate intervals, respectively). The covariates residual cover (RC) and PS are correlated across all values (Pearson's product-moment correlation, $r=0.46, P<0.01$ ), but the correlation is nonsignificant at PS $>57(r=0.19, P=0.191)$. The PS values graphed therefore represent the point at which RC and PS no longer demonstrate a correlation (58), and the $90 \%$ quantile (85). Values for NVEG are $10 \%$ quantile $(1.00 \mathrm{dm})$, mean $(2.23 \mathrm{dm})$, and $90 \%$ quantile $(4.00)$.
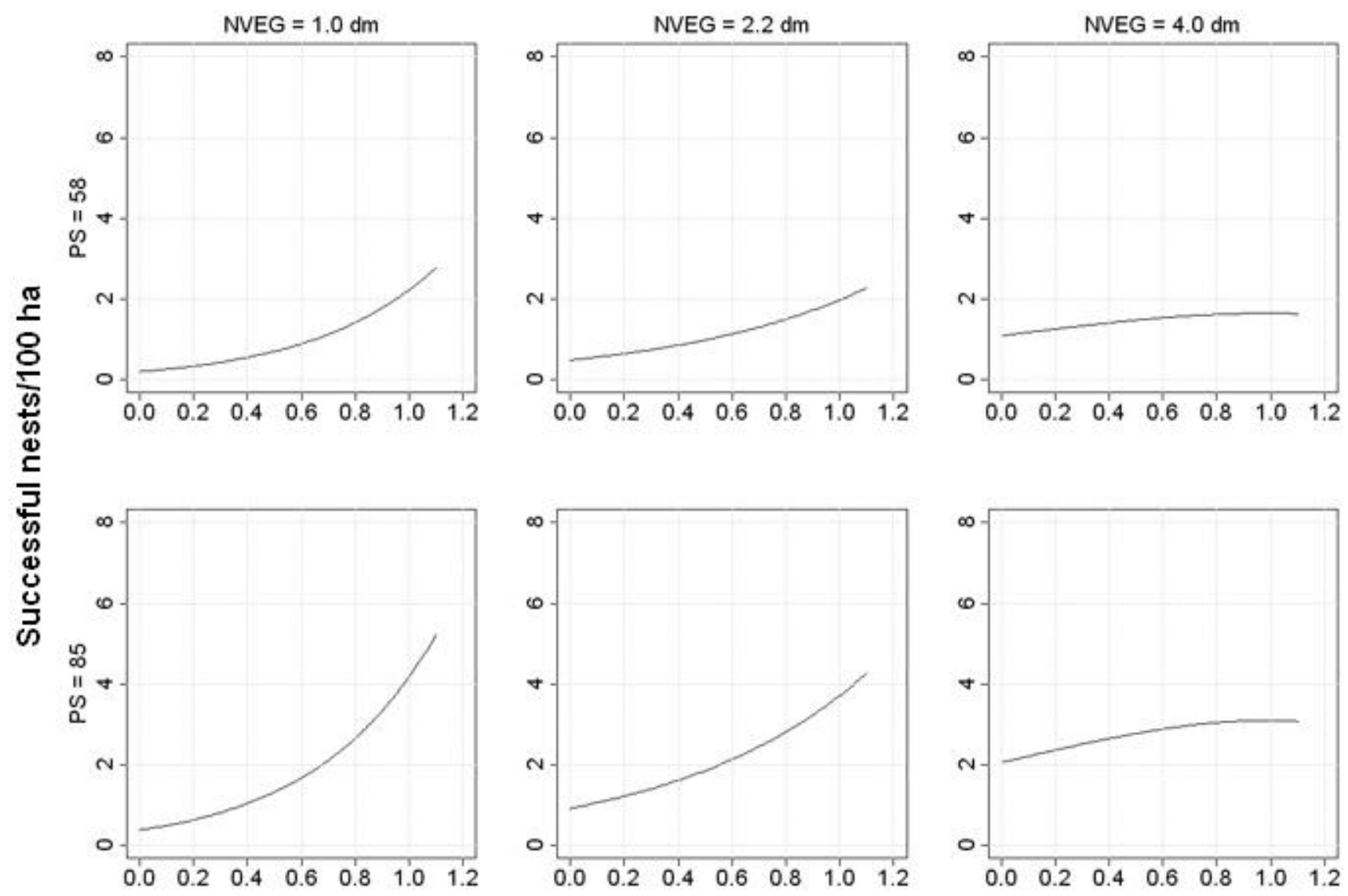

Field residual cover (dm)

lower levels of field-scale residual cover. Higher nesting success in grazed fields may occur because predators respond negatively to low prey density (Clark and Nudds 1991, Lariviére and Messier 1998). In addition to reducing duck nest densities, grazing generally reduces the abundance of small mammals such as voles (Microtus spp.; Grant et al. 1982, Runge 2005), which are an important prey item for Parkland meso-predators. If predators avoid habitats with low overall prey density, such as more intensively grazed areas, the success of the ducks nesting in these habitats may be greater than in areas more attractive to predators. Clark et al. (1999) found that Ring-necked Pheasants (Phasianus colchicus) nesting in small isolated habitat patches in a highly fragmented agricultural landscape in Iowa had higher nesting success than pheasants nesting in some larger blocks of habitat. 
These small isolated habitats likely provided few foraging opportunities for predators, resulting in lower overall predator activity and higher nesting success than in larger habitat blocks. Heavily grazed pasturelands provide a limited number of small isolated habitat patches suitable for nesting, likely attracting few predators and resulting in higher duck nesting success.

\section{CONCLUSION}

Our results indicate that nesting females are most successful at nest sites with above-average nest-site vegetation density within fields with low levels of residual cover. However, very few females choose, or are able to find, suitable nest sites within heavily grazed pastures. This results in the greatest duck production still being realized in lightly grazed or idled fields, which are uncommon in typical pasture lands. Fortunately, females selecting densely vegetated nest sites within most levels of residual cover occurring in pasturelands tended to exceed the hypothesized threshold of nesting success needed to maintain a population. Therefore, pasture land management should aim to optimize the number of suitable nest sites (i.e., vegetation density $\geq 2.2 \mathrm{dm}$ ) within the constraints of cattle production.

High grazing intensities are common in the Aspen Parkland. Greater and more consistent precipitation in the Aspen Parkland, relative to the more arid and drought-prone grasslands, generally leads producers to graze at higher utilization rates with fewer perceived negative consequences (Holecheck et al. 1999). Also, mixed farming of annual crops and beef production is more common in the Aspen Parkland than in the grasslands, with income from cattle production typically second to that from annual crops (Statistics Canada 2003). This results in less impetus for investing time in rangeland management relative to annual crop operations. These factors lead to an "industry standard" grazing level that results in high utilization rates in pasture lands. However, persistent heavy grazing leads to lower forage production because of: (1) soil compaction, (2) low litter levels, (3) reduced root biomass, (4) less moisture infiltration into the soil, and (5) increased soil temperatures (Holecheck et al. 2004). In a review of the literature on grazing systems and stocking rates in the Great Plains and the western USA, VanPoollen and Lacey (1979) found that plant production increases on average $35 \%$ when the stocking rate is reduced from heavy to moderate. Moderate stocking rates also result in higher net financial returns, relative to heavy stocking, on native pastures (Holecheck et al. 1999).

Working with cattle producers to increase their awareness of the economic benefits of reduced grazing intensity could result in improved nesting habitat across significant areas of the Aspen Parkland. Currently, there are 9.3 million ha of pasture land in the Aspen Parkland (Statistics Canada 2003). This study suggests that, although lightly grazed or idled fields may produce more ducks, reducing grazing intensity across Parkland pasture lands will increase the availability of highly successful nest sites to upland nesting ducks.

Responses to this article can be read online at: http://www.ace-eco.org/vol3/iss2/art6/responses/

\section{Acknowledgments:}

The Institute for Wetland and Waterfowl Research (IWWR), Alberta provincial operations of Ducks Unlimited Canada (DUC), and the Alberta North American Waterfowl Management Plan Partnership provided funding and/or logistical support for this project. Reviews by M.-A. Villard, M. Drever and 2 anonymous reviewers improved the manuscript. We thank field crew leaders and technicians B. Fletcher, J. Skelton, C. Sousa, E. Tymensen, C. Bolli, K. Burkhart, D. Cross, S. Folk, J. Kenyon, J. Naples, R. Paul, and S. Rohatyn. We worked closely with R. Stavne during the study and thank him for his assistance. DUC staff from Alberta provided invaluable assistance with field selection, landowner contacts, and at various other times during the field seasons. We also thank N. Hopkins of DUC for Geographical Information System support for this project and L. Armstrong of IWWR for analytical consultations. Lastly, we thank all the landowners who gave permission to conduct this study on their lands.

\section{LITERATURE CITED}

Adams, B. W., G. Ehlert, C. Stone, D. Lawrence, M. Alexander, M. Willoughby, C. Hincz, D. Moisey, A. Burkinshaw, and J. Carlson. 2003. Rangeland health assessment for grassland, forest 
and tame pasture. Publication Number T/044. Alberta Sustainable Resource Development, Public Lands and Forests Division, Rangeland Management Branch, Edmonton, Alberta, Canada. Available online at: http://www.srd.gov.ab.ca/lands/managing publicland/rangemanagement/pdf/Range Health $\mathrm{F}$ ield Workbook.pdf.

Barker, W. T., K. K. Sedivec, T. A. Messmer, K. F. Higgins, and D. R. Hertel. 1990. Effects of specialized grazing systems on waterfowl production in southcentral North Dakota. Transactions of the 55th North American Wildlife and Natural Resources Conference 55:462-474.

Beauchamp, W. D., R. R. Koford, T. D. Nudds, R. G. Clark, and D. H. Johnson. 1996. Long-term declines in nest success of prairie ducks. Journal of Wildlife Management 60:247-257.

Bowes, G. G., and D. T. Spurr. 1996. Control of aspen poplar, balsam poplar, prickly rose and western snowberry with metsulfuron-methyl and 2,4-D. Canadian Journal of Plant Science 76:885-889.

Burnham, K.P., and D. R.Anderson. 1998. Model selection and inference: a practical informationtheoretic approach. Springer-Verlag, New York, New York, USA.

Clark, R. G., and T. D. Nudds. 1991. Habitat patch size and duck nesting success: the crucial experiments have not been performed. Wildlife Society Bulletin 19:534-543.

Clark, W. G., R. A. Schmitz, and T. R. Bogenschutz. 1999. Site selection and nest success of ring-necked pheasants as a function of location in Iowa landscapes. Journal of Wildlife Management 63:976-989.

Cowardin, L. M., D. S. Gilmer, and C. W. Shaiffer. 1985. Mallard recruitment in the agricultural environment of North Dakota. Wildlife Monographs 92:1-37.

Drever, M. C., T. D. Nudds, and R. G. Clark. 2007. Agricultural policy and nest success of prairie ducks in Canada and the United States. Avian Conservation and Ecology 2(2):5. Available online at: http://www.ace-eco.org/vol2/iss2/art5/.

Duebbert, H. F. 1969. High nest density and hatching success of ducks on South Dakota CAP land. Transactions of the 34th North American Wildlife and Natural Resources Conference 34:218-228.

Duebbert, H. F., J. T. Lokemoen, and D. E. Sharp. 1986. Nest sites of ducks in grazed mixed-grass prairie in North Dakota. Prairie Naturalist 18:99-108.

Environment Canada. 2006. Canadian climate normals 1971-2000. Environment Canada, Ottawa, Ontario, Canada. Available online at: http://www.c limate.weatheroffice.ec.gc.ca/climate normals/results e. html.

Gilbert, D. W., D. R. Anderson, J. K. Ringleman, and M. R. Szymczak. 1996. Response of nesting ducks to habitat management on the Monte Vista National Wildlife Refuge Colorado. Wildlife Monographs 131:1-44.

Grant, W. E., E. C. Birney, N. R. French, and D. M. Swift. 1982. Structure and productivity of grassland small mammal communities related to grazing-induced changes in vegetative cover. Journal of Mammology 63:248-260.

Greenwood, R. J., A. B. Sargeant, D. H. Johnson, L. M. Cowardin, and T. L. Shaffer. 1995. Factors associated with duck nest success in the Prairie Pothole Region of Canada. Wildlife Monographs 128:1-57.

Hoekman, S. T., L. S. Mills, D. W. Howerter, J. H. Devries, and I. J. Ball. 2002. Sensitivity analysis of the life cycle of midcontinent mallards. Journal of Wildlife Management 66:883-900.

Holecheck, J. L., H. Gomez, F. Molinar, and D. Galt. 1999. Grazing studies: what we've learned. Rangelands 21:12-16.

Holecheck, J. L., R. D. Pieper, and C. H. Herbal. 2004. Range management: principles and practices. Prentice-Hall, Upper Saddle River, New Jersey, USA.

Johnson, D. H., and J. W. Grier. 1988. Determinants of breeding distributions of ducks. Wildlife Monographs 100:1-37.

Johnson, D. H., J. D. Nichols, and M. D. Schwartz. 1992. Population dynamics of breeding waterfowl. Pages 446-485 in B. D. J. Batt, A. D. Afton, M. G. Anderson, C. D. Ankney, D. H. Johnson, J. A. Kadlec, and G. L. Krapu, editors. Ecology and management of breeding waterfowl. 
University of Minnesota Press, Minneapolis, Minnesota, USA.

Klett, A. T., H. F. Duebbert, C. A. Faanes, and K. F. Higgins. 1986. Techniques for studying nest success of ducks in upland habitats in the Prairie Pothole Region. U.S. Fish and Wildlife Service Resource Publication 158. U.S. Fish and Wildlife Service, Washington D.C., USA.

Klett, A. T., T. L. Shaffer, and D. H. Johnson. 1988. Duck nest success in the Prairie Pothole Region. Journal of Wildlife Management 52:431-440.

Kirsch, L. M., H. F. Duebbert, and A. D. Kruse. 1978. Grazing and haying effects on habitat of upland nesting birds. Transactions of the 43th North American Wildlife and Natural Resources Conference 43:486-497.

Kruse, A. D., and B. S. Bowen. 1996. Effects of grazing and burning on densities and habitats of breeding ducks in North Dakota. Journal of Wildlife Management 60:233-246.

Lariviére, S., and F. Messier. 1998. Effect of density and nearest neighbours on simulated waterfowl nests: Can predators recognize highdensity nesting patches? Oikos 83:12-20.

Neter, J., M. H. Kutner, C. J. Nachtsheim, and W. Wasserman. 1996. Applied linear statistical models. McGraw-Hill, Boston, Massachusetts, USA.

Robel, R. J., J. N. Briggs, A. D. Dayton, and L. C. Hulbert. 1970. Relationships between visual obstruction measurements and weight of grassland vegetation. Journal of Range Management 23:295-297.

Rotella, J. J., S. J. Dinsmore, and T. L. Schaffer. 2004. Modeling nest-survival data: a comparison of recently developed methods that can be implemented in MARK and SAS. Animal Biodiversity and Conservation 27:187-204.

Rotella, J. J., M. L. Taper, S. E. Stephens, and M. S. Lindberg. 2007. Extending methods for modeling heterogeneity in nest-survival data using generalized mixed models. Studies in Avian Biology 34:34-44.
Rowe, J. S. 1987. Status of the Aspen Parkland in the Prairie Provinces. Pages 27-33 in G. L. Holroyd, W. B. McGillivray, P. H. R. Stepney, D. M. Ealey, G. C. Trottier, and K. E. Eberhart, editors. Proceedings of the Workshop on Endangered Species in the Prairie Provinces. Natural History Occasional Paper No. 9. Provincial Museum of Alberta, Edmonton, Alberta, Canada.

Runge, J. P. 2005. Spatial population dynamics of Microtus in grazed and ungrazed grasslands. Dissertation. University of Montana, Missoula, Montana, USA.

Sargeant, A. B., and D. G. Raveling. 1992. Mortality during the breeding season. Pages 396-422 in B. D. J. Batt, A. D. Afton, M. G. Anderson, C. D. Ankney, D. H. Johnson, J. A. Kadlec, and G. L. Krapu, editors. Ecology and management of breeding waterfowl. University of Minnesota Press, Minneapolis, Minnesota, USA.

SAS Institute. 2001. SAS/STAT user's guide. SAS Institute, Cary, North Carolina, USA.

Sedivec, K. K. 1989. Effects of specialized grazing systems on upland nesting waterfowl production in southcentral North Dakota. Thesis. North Dakota State University, Fargo, North Dakota, USA.

Smith, A. G., J. H. Stoudt, and J. B. Gollop. 1964. Prairie potholes and marshes. Pages 39-50 in J. P. Linduska, editor. Waterfowl tomorrow. U.S. Government Printing Office, Washington, D.C., USA.

Statistics Canada. 2003. 2001 census: census of agriculture. Statistics Canada, Ottawa, Ontario, Canada. Available online at: http://www.statcan.gc. $\mathrm{ca} / \mathrm{bsolc} /$ olc-cel/olc-cel?lang=eng $\&$ Scatno $=95 \mathrm{~F} 0301 \mathrm{X}$

Stewart, R. E., and H. A. Kantrud. 1971. Classification of natural ponds and lakes in the glaciated prairie region. U.S. Fish and Wildlife Service Resource Publication 92. U.S. Fish and Wildlife Service, Washington D.C., USA.

Sturdivant, R. X., J. J. Rotella, and R. E. Russell. 2007. A smoothed residual based goodness-of-fit statistic for nest-survival models. Studies in Avian Biology 34:45-54. 
Sugden, L. G., and G. W. Beyersbergen. 1987. Effects of nesting cover density on American crow predation on simulated duck nests. Journal of Wildlife Management 51:481-485.

Turner, B. C., G. S. Hochbaum, F. D. Caswell, and D. J. Nieman. 1987. Agricultural impacts on wetland habitats on the Canadian Prairies, 19811985. Transactions of the 52nd North American Wildlife and Natural Resource Conference 52:206-215.

U.S. Fish and Wildlife Service. 2007. Waterfowl breeding population and habitat survey, 2007. U.S. Department of the Interior, Washington D.C., USA. Available online at: http://mbdcapps.fws.gov/.

VanPoollen, H. W., and J. R. Lacey. 1979. Herbage response to grazing systems and stocking intensities. Journal of Range Management 32:250-253.

Weller, M. W. 1956. A simple field candler for waterfowl eggs. Journal of Wildlife Management 20:111-113.

White, G. C., and R. E. Bennetts. 1996. Analysis of frequency count data using the negative binomial distribution. Ecology 77:2549-2557. 